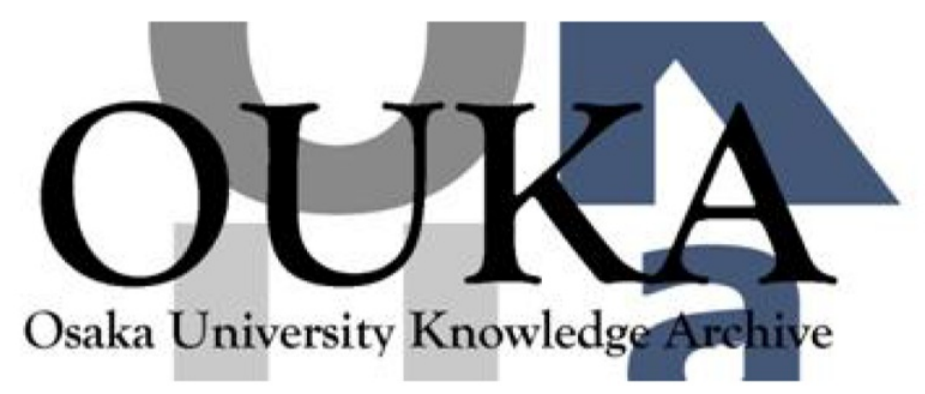

\begin{tabular}{|c|l|}
\hline Title & $\begin{array}{l}\text { The chromosome peripheral proteins play an } \\
\text { active role in chromosome dynamics }\end{array}$ \\
\hline Author(s) & Matsunaga, Sachihiro; Fukui, Kiichi \\
\hline Citation & Biomolecular Concepts. 1(2) p. 157-p. 164 \\
\hline Issue Date & 2010 \\
\hline oaire:version VoR \\
\hline URL & https://hdl. handle.net/11094/78971 \\
\hline rights & \\
\hline Note & \\
\hline
\end{tabular}

Osaka University Knowledge Archive : OUKA

https://ir. Library. osaka-u. ac. jp/

Osaka University 


\section{The chromosome peripheral proteins play an active role in chromosome dynamics}

\author{
Sachihiro Matsunaga and Kiichi Fukui* \\ Department of Biotechnology, Graduate School of \\ Engineering, Osaka University, 2-1 Yamadaoka, \\ Suita 565-0871, Osaka, Japan \\ * Corresponding author \\ e-mail: kfukui@bio.eng.osaka-u.ac.jp
}

\begin{abstract}
The chromosome periphery is a chromosomal structure that covers the surface of mitotic chromosomes. The structure and function of the chromosome periphery has been poorly understood since its first description in 1882. It has, however, been proposed to be an insulator or barrier to protect chromosomes from subcellular substances and to act as a carrier of nuclear and nucleolar components to direct their equal distribution to daughter cells because most chromosome peripheral proteins (CPPs) are derived from the nucleolus or nucleus. Until now, more than 30 CPPs were identified in mammalians. Recent immunostaining analyses of CPPs have revealed that the chromosome periphery covers the centromeric region of mitotic chromosomes in addition to telomeres and regions between two sister chromatids. Knockdown analyses of CPPs using RNAi have revealed functions in chromosome dynamics, including cohesion of sister chromatids, kinetochore-microtubule attachments, spindle assembly and chromosome segregation. Because most CPPs are involved in various subcellular events in the nucleolus or nuclear at interphase, a temporal and spatialspecific knockdown method of CPPs in the chromosome periphery will be useful to understand the function of chromosome periphery in cell division.
\end{abstract}

Keywords: cell division; chromosome dynamics; chromosome periphery; chromosome surface; nucleolar proteins.

\section{Introduction}

The chromosome is one of the most dynamic subcellular structures, which is formed at the beginning of cell division when extended chromatin is condensed. Chromosomes then align along the spindle equator and move to the opposite spindle poles. After equal separation, the chromosomes become dispersed and nuclei are reconstructed. Schneider first described chromosomes during mitosis in 1873 (1) and since this time many researchers have been fascinated by the aesthetic dynamics of chromosomes during cell division.
Although over 130 years have passed since Schneider's discovery, chromosome dynamics is still a hot topic in biology.

Most organelles have single or double membranes to separate them from the cytoplasmic environment. In contrast to the nucleus, which has the nuclear envelope consisting of a double membrane, chromosomes have no membranes. However, chromosomes do have a distinct surface layer, the chromosome periphery. The chromosome periphery covers chromosomes, including the regions between two sister chromatids. The chromosome periphery is also known as the chromosome surface, chromosome pellicle, perichromosomal matrix, perichromosomal layer, perichromosomal region and perichromosomal sheath. The chromosome periphery is widely found in eukaryotes, including insects, animals and plants (2). The peripheral or related structure of nucleoid in bacteria is not reported (3).

Based on studies of nucleoli in maize, McClintock suggested that the chromosome periphery could play a functional role (4). However, although the chromosome periphery is known as a conserved structure in eukaryotes, its function is not yet known (5-7). Recent knockdown analyses of some chromosome peripheral proteins (CPPs) including histone H1.X, nucleolin, nucleophosmin (NPM), PinX1 and RRS1 have, however, have begun to reveal the secrets of the chromosome periphery. Here, we review the current understanding of the chromosome periphery and CPPs, and propose a new hypothesis that chromosome periphery actively functions in chromosome dynamics.

\section{What is the chromosome periphery?}

The chromosome periphery was first described by Strasburger (8). He reported that nucleolar components unite with the chromatin or chromosomes before the breakdown of the nuclear envelope. After this description, cytological analyses revealed the morphological character of the chromosome periphery. The presence of a layer around chromosomes during mitosis was confirmed by light microscopy (9-11). Autoradiography revealed that nucleolar proteins, ribonucleoproteins, were localized in the chromosome periphery (12). Electron microscopy demonstrated that nucleolar proteins coated mitotic chromosomes until nucleolar reconstruction (13-15). Moreover, the chromosome periphery consists of closely packed dense granules which are often in direct contact with chromatin (16). Immunostaining with antibodies against several CPPs and localization analyses of GFP-fused CPPs also demonstrated that the chromosome periphery is not an experimental artifact but a chromosome structure (7, 17). Recent proteome analyses of metaphase chromosomes 
revealed that human chromosomes consist of four layers, including the chromosome periphery (17). Proteomic analyses under different conditions indicated that CPPs remain to be associated even with highly purified chromosomes. In contrast, most chromosomal coating proteins, including mitochondrial or endoplasmic reticulum (ER) proteins, are lost from chromosomes under the same conditions $(17,18)$. This suggests that the chromosome periphery is maintained as a chromosomal structure, resisting isolation and purification procedures or mechanical treatments.

\section{Classification of chromosome peripheral proteins (CPPs)}

CPPs in mammalians, listed in Table 1, belong to nuclear or nucleolar proteins at interphase. Most CPPs among more than 30 CPPs are derived from the nucleolus. Most nucleolarderived CPPs begin to be localized in the chromosome periphery immediately after nucleoli disassembly and are transferred to reassembled nucleoli at telophase. In contrast, a heterogeneous nuclear ribonucleoprotein, hnRNP2A (35), and a large preribosomal complex-associating protein, NO66 (46), are localized in the chromosome periphery only at anaphase. A group of nuclear envelope components is specifically localized in the chromosome periphery at telophase (19). The chromosome periphery at telophase, which is involved in nucleus reassembly, has different characteristics from that at prophase to anaphase. Analyses of barrier-toautointegration factor (BAF) revealed that the chromosome periphery at early telophase has a distinct core region consisting of a BAF scaffold for the accumulation of nuclear envelope components, including LAP $2 \alpha$, emerin and lamin A $(19,21,40)$. Fluorescence recovery after photobleaching (FRAP) analyses of GFP-BAF demonstrated that BAF forms an immobile structure in the core region of the telophase chromosome periphery (21).

The function of most CPPs at interphase is mainly in RNA-related events, including RNA processing, RNA metabolism, ribosome assembly, transcription and splicing. Interestingly, the apoptosis regulator, B-cell lymphoma-2 (Bcl-2) is a member of the CPPs $(65,66)$. Bcl-2 functions mainly in mitochondria as a negative regulator against cell death progression, a function that is not directly related to RNA-related pathways. Microscopic studies have revealed the interphase localization of Bcl-2 at multiple subcellular localizations: in nuclear outer membrane, nucleoplasm, endoplasmic reticulum membrane and mitochondrial membranes $(67,68)$. Coimmunostaining with Ki-67 and nucleolin confirmed Bcl-2 colocalization in the chromosome periphery during mitosis but $\mathrm{Bcl}-2$ function on the chromosome periphery remains unknown (22).

\section{CPPs function in chromosome alignment, segregation and spindle assembly}

Although the presence of the chromosome periphery has been established, its function has remained elusive. Several roles of the chromosome periphery have been proposed (2, $6,7)$. First, it might act as a structural barrier to protect the chromosome from cytoplasmic components. Although the chromosome periphery is not rigid like an exoskeleton, large molecules cannot penetrate into chromosomes. This suggests that the chromosome periphery coats and insulates chromosomes from the surrounding cytoplasmic materials (69). Second, a role in chromosome condensation was proposed based on the temporal and spatial correlation of condensation with the accumulation of some CPPs on chromosomes $(70,71)$. Moreover, the chromosome periphery might also help maintain the compacted state of chromatin because the chromosome periphery appears to be in contact with chromosomes during mitosis (16). By contrast, recent research has revealed that the chromosome periphery has no relationship with chromosome condensation because condensins have been shown to play the main role in chromosome condensation as internal scaffolds (72). In fact, knockdown of a series of CPPs including histone H1.X, nucleolin, NPM and RRS1 does not influence chromosome condensation $(18,30,49,60)$.

The most credible hypothesis of the function of the chromosome periphery is as a carrier of subcellular components to daughter cells through cell division $(2,13,16,73,74)$. This hypothesis is supported by the fact that the chromosome periphery contains most of the nucleolar proteins. Nucleoli disassemble at the beginning of mitosis and they begin reassembly at anaphase. Nucleolar proteins in the chromosome periphery are equally transported to the two daughter cells and are incorporated into the nucleoli within the reconstructed nuclei. Based on such dynamic movement of nucleolar proteins on chromosomes, traditional researchers have stated that all forms of nucleoli could be directly derived from the chromosomes (75). McClintock proposed that the release of nucleolar substance from the chromosome periphery might be necessary before the chromatin can again function properly (4).

Chromosome passenger proteins such as Aurora B, borealin, INCENP and survivin are also known to use chromosomes as a vessel in cell division (76). These proteins bind to chromosomes at prophase and detach from metaphase plate-localized chromosomes during metaphase. At anaphase, they form central spindles and at telophase they function in the formation of cleavage furrow. Transportation on chromosomes enables proteins to reach the correct amount and position of future contraction sites. Based on the analogy with passenger proteins, it has been argued that CPPs attached to the chromosome within the chromosome periphery are prevented from dispersal into the cytoplasm. Therefore, CPPs seemed to have no active function on the chromosome; they merely use the chromosome as a means of transport to daughter cells (77). However, the function of the chromosome periphery might not be so simple to the carrying of subcellular components into two new daughter cells. Most nucleolar proteins, after nuclear envelope breakdown, are dispersed in the cytoplasm and are then packed into small organelles, nucleolar-derived foci (NDFs) at anaphase $(5,6)$. NDFs are equally distributed into the two daughter cells and fuse to become a prenucleolar body at 
Table 1 Chromosome peripheral proteins in mammalians.

\begin{tabular}{|c|c|c|c|c|}
\hline Protein name & Interphase localization & Duration & Function & References \\
\hline BAF (BANF1) & Nuclear & $\mathrm{T}$ & $\begin{array}{l}\text { Nuclear assembly } \\
\text { DNA binding protein } \\
\text { DNA synthesis progression }\end{array}$ & $(19-21)$ \\
\hline $\mathrm{Bcl} 2$ & $\begin{array}{l}\text { Nuclear, mitochondria, } \\
\text { endoplasmic reticulum }\end{array}$ & $\mathrm{P} \rightarrow \mathrm{A}$ & Apoptotic regulation & $(22)$ \\
\hline $\mathrm{BCR}$ & Nuclear & $\mathrm{P} \rightarrow \mathrm{T}$ & $\begin{array}{l}\text { Chronic myelogenous leukemia } \\
\text { Serine/threonine kinase } \\
\text { GTPase-activating protein }\end{array}$ & $(23)$ \\
\hline BOP1 & Nucleolar & $\mathrm{PM} \rightarrow \mathrm{ET}$ & Ribosome biogenesis & $(24,25)$ \\
\hline CRFG (GTBP4, NGB, NOG1) & Nucleolar & $\mathrm{PM} \rightarrow \mathrm{LA}$ & $\begin{array}{l}\text { GTP binding protein } \\
\text { Chronic renal failure }\end{array}$ & $(26)$ \\
\hline $\mathrm{EBP} 2$ & Nucleolar & $\mathrm{PM} \rightarrow \mathrm{T}$ & $\begin{array}{l}\text { Epstein-Barr nuclear antigen } \\
\text { 1-binding protein }\end{array}$ & $(27)$ \\
\hline Emerin & Nuclear & $\mathrm{T}$ & Component of nuclear membrane & $(19,21)$ \\
\hline Fibrillarin & Nucleolar & $\mathrm{PM} \rightarrow \mathrm{ET}$ & $\begin{array}{l}\text { Processing preribosomal RNA } \\
\text { Nuclear morphogenesis } \\
\text { Autoimmune disease scleroderma }\end{array}$ & $(28-32)$ \\
\hline FLJ23637 & Nucleolar & $\mathrm{PM} \rightarrow \mathrm{LA}$ & WD repeat-containing protein & (33) \\
\hline hnRNP A2 & Nucleolar & A & $\begin{array}{l}\text { Regulation of mRNA metabolism } \\
\text { Telomere maintenance }\end{array}$ & $(34,35)$ \\
\hline H1.X & Nucleolar & $\mathrm{PM} \rightarrow \mathrm{ET}$ & $\begin{array}{l}\text { Mitotic progression } \\
\text { Microtubule-kinetochore } \\
\text { attachments }\end{array}$ & $(36)$ \\
\hline $\mathrm{Ki}-67$ & $\begin{array}{l}\text { Nucleolar, } \\
\text { nuclear }\end{array}$ & $\mathrm{P} \rightarrow \mathrm{T}$ & $\begin{array}{l}\text { Cell proliferation } \\
\text { Organization of chromatin structure }\end{array}$ & $(37,38)$ \\
\hline Ku70/80 complex & Nuclear & $\mathrm{P} \rightarrow \mathrm{T}$ & $\begin{array}{l}\text { DNA-PKcs-dependent } \\
\text { double-strand break repair } \\
\text { Non-homologous DNA end joining } \\
\text { Telomere maintenance }\end{array}$ & $(39)$ \\
\hline Lamin A (LMNA) & Nuclear & $\mathrm{T}$ & $\begin{array}{l}\text { Component of nuclear matrix } \\
\text { Regulation of nuclear stability } \\
\text { Regulation of gene expression }\end{array}$ & $(19,21)$ \\
\hline LAP $2 \alpha(\mathrm{LAP} 2 \mathrm{~A})$ & Nuclear & $\mathrm{T}$ & Nuclear assembly & $(21,40)$ \\
\hline $\begin{array}{l}\text { MPHOSPH10 (CT90, } \\
\text { MPP10P) }\end{array}$ & Nucleolar & $\mathrm{PM} \rightarrow \mathrm{ET}$ & $\begin{array}{l}\text { U3 small nucleolar ribonucleoprotein } \\
\text { complex } \\
\text { rRNA processing }\end{array}$ & $(41)$ \\
\hline NAT10 (KIAA1709) & Nucleolar & $\mathrm{PM} \rightarrow \mathrm{LA}$ & $\begin{array}{l}\mathrm{N} \text {-acetyltransferase } \\
\text { Regulation of cytokinesis in midbody } \\
\text { Acetylation of microtubules }\end{array}$ & $(33,42)$ \\
\hline NIFK & Nucleolar & $\mathrm{P} \rightarrow \mathrm{T}$ & Cell proliferation & $(43)$ \\
\hline No55 & Nucleolar & $\mathrm{PM} \rightarrow \mathrm{T}$ & Prostate cancer & $(44,45)$ \\
\hline NO66 & Nucleolar & A & $\begin{array}{l}\text { Jumonji family histone demethylase } \\
\text { Osteoblast differentiation and bone } \\
\text { formation }\end{array}$ & $(46,47)$ \\
\hline Nop52 & Nucleolar & $\mathrm{PM} \rightarrow \mathrm{ET}$ & Pre-rRNA processing & $(24,32)$ \\
\hline Nrap & Nucleolar & $\mathrm{PM} \rightarrow \mathrm{ET}$ & Pre-rRNA primary transcription & $(48)$ \\
\hline Nucleolin & Nucleolar & $\mathrm{PM} \rightarrow \mathrm{ET}$ & $\begin{array}{l}\text { Pre-rRNA processing } \\
\text { Cytoplasmic-nucleolar transport } \\
\text { Mitotic progression } \\
\text { Microtubule-kinetochore attachment }\end{array}$ & $(31,49,50)$ \\
\hline $\begin{array}{l}\text { Nucleophosmin } \\
\text { (NPM, B23) }\end{array}$ & $\begin{array}{l}\text { Nucleolar, } \\
\text { nuclear }\end{array}$ & $\mathrm{PM} \rightarrow \mathrm{ET}$ & $\begin{array}{l}\text { Ribosomal assembly and transport } \\
\text { Mitotic progression } \\
\text { Centrosome duplication } \\
\text { Microtubule-kinetochore attachment } \\
\text { Nuclear morphogenesis }\end{array}$ & $(28-30,50,51)$ \\
\hline RBBP6 (PSP-R) & Nucleolar & $\mathrm{PM} \rightarrow \mathrm{ET}$ & $\begin{array}{l}\text { Retinoblastoma binding protein } \\
\text { Camptothecin-induced apoptosis } \\
\text { mRNA processing } \\
\text { Ubiquitin-like pathways }\end{array}$ & $(52,53)$ \\
\hline
\end{tabular}


Table 1 (Continued)

\begin{tabular}{|c|c|c|c|c|}
\hline Protein name & Interphase localization & Duration & Function & References \\
\hline Pescadillo (PES1) & $\begin{array}{l}\text { Nucleolar, } \\
\text { nuclear }\end{array}$ & $\mathrm{PM} \rightarrow \mathrm{ET}$ & $\begin{array}{l}\text { DNA replication } \\
\text { Ribosome biogenesis } \\
\text { Transformation and immortalization }\end{array}$ & $(54,55)$ \\
\hline PinX1 & Nucleolar & $\mathrm{PM} \rightarrow \mathrm{ET}$ & $\begin{array}{l}\text { Mitotic progression } \\
\text { Chromosome segregation } \\
\text { Microtubule binding protein }\end{array}$ & $(56,57)$ \\
\hline RH-II/Gu & Nucleolar & PM & RNA helicase & (58) \\
\hline Ribosomal protein S1 & Nucleolar & $\mathrm{M} \rightarrow \mathrm{A}$ & $\begin{array}{l}\text { Component of the small } \\
\text { ribosomal subunit }\end{array}$ & (59) \\
\hline RRS1 & Nucleolar & $\mathrm{PM} \rightarrow \mathrm{ET}$ & $\begin{array}{l}\text { Mitotic progression } \\
\text { Centromeric protection } \\
\text { Ribosome biogenesis }\end{array}$ & $(60)$ \\
\hline SURF-6 & Nucleolar & $\mathrm{PM} \rightarrow \mathrm{ET}$ & $\begin{array}{l}\text { DNA and RNA binding protein } \\
\text { Processing of rRNA }\end{array}$ & (61) \\
\hline Tsg118 & Nucleolar & $\mathrm{PM} \rightarrow \mathrm{ET}$ & Testis development & $(62,63)$ \\
\hline U-snRNP & Nucleolar & $\mathrm{M} \rightarrow \mathrm{ET}$ & $\begin{array}{l}\text { Component of the spliceosome } \\
\text { Pre-mRNA splicing }\end{array}$ & (64) \\
\hline
\end{tabular}

P, prophase; PM, prometaphase; M, metaphase; A, anaphase; LA, late anaphase; T, telophase; ET, early telophase.

telophase. With regard to the equal delivery and precise recruiting of nucleolar components, NDFs or another delivery system could replace the function of the chromosome periphery. In yeast, Saccharomyces cerevisiae and Schizosaccharomyces pombe, whose nuclear envelope never breaks down during cell division, there is no chromosome periphery and nucleoli are not dispersed during mitosis (78). Rather, they are partitioned and divided between two daughter cells $(5,6)$.

Since the application of RNA interference (RNAi) to mammalian cells (79), knockdown analysis with RNAi has been a powerful tool to study the function of essential proteins. This is because knockdown experiments can maintain a minimum level of protein to enable the cell survival, unlike knockout experiments. Depletion of nucleolin, one of major nucleolar and CPPs, was performed by RNAi (27). Nucleolin depletion caused the disappearance of other nucleolar proteins, including fibrillarin and NPM, from the chromosome periphery, suggesting that nucleolin recruits CPPs to the chromosome periphery. This depletion results in mitotic delay, which is then caused by activation of the spindle checkpoint. In fact, nucleolin depletion induced two types of pronounced defect in chromosome congression: misalignment and non-alignment. In the misalignment phenotype, several chromosomes remained near the spindle poles, although the other chromosomes aligned at the spindle equator, whereas, in the non-alignment phenotype, most of the chromosomes remained dispersed. These findings demonstrate that nucleolin is involved in normal chromosome congression. Why does nucleolin absence from the chromosome periphery induce mitotic delay? Detailed analyses of kinetochore-microtubule attachments and dynamic analyses of chromosome oscillation in living cells revealed that the failure of chromosome congression is due to an inability of the kinetochore-microtubule interactions to maintain sufficient tension. This is the first report showing that a CPP can contribute to chromosome congression during mitosis.
This function of nucleolin in the kinetochore seems to be inconsistent with the definition of the chromosome periphery, based on the localization pattern of CPPs. The chromosome periphery was not thought to cover the centromeric region because previous cytological analyses showed that immunolocalization of CPPs could not be detected in centromeric regions $(69,73)$. Such exclusion from centromeres was thought to be due to the accumulation of kinetochore proteins (2). Only Ki-67 was reported to be localized to centromeric regions of the chromosome periphery $(58,80)$. However, recent immunostaining results using antibodies against fibrillarin, nucleolin, NPM, PinX1 and RRS1 demonstrated their localization in the centromeric regions of the chromosome periphery, including in the vicinity of the outer kinetochore (Figure 1) (28-30, 49, 57, 60). A new protocol for metaphase chromosome spread preparation (81) contributed to the detection of CPPs including fibrillarin, histone H1.X, NPM, nucleolin and RRS1, around the centromeric region.

Following the discovery of nucleolin function in the chromosome periphery, other CPPs, including histone H1.X, NPM, PinX1 and RRS1, have also been shown to function in chromosome congression (28-30, 57, 60, 57, 82). Knockdown of a variant of histone H1, H1.X, and a centrosomebinding protein, NPM, induces defects in kinetochoremicrotubule attachments similar to nucleolin depletion, resulting in a prolonged time from nuclear envelope breakdown to chromosome alignment $(28-30,82)$. Depletion of a ribosome biogenesis regulatory protein, RRS1, induces the disappearance of Shugosin 1, which is responsible for centromeric protection (60). This results in premature sister chromatid separation. PinX1 was identified by its interaction with the telomere maintenance complex and also interacts with nucleolin in the chromosome periphery and has the ability of microtubule binding (56). Depletion of PinX1 by RNAi induced mitotic delay, which resulted from a defect in kinetochore-microtubule attachment and chromosome segregation (57). 


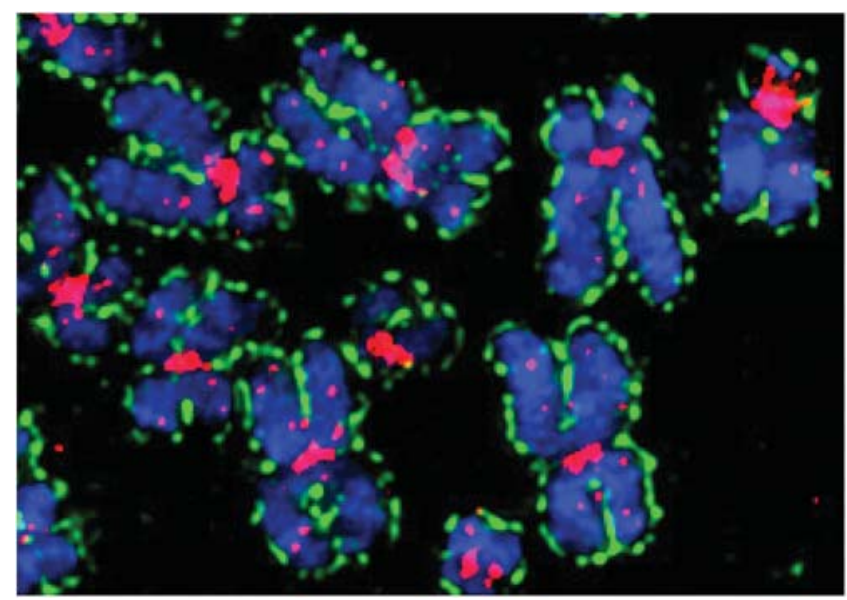

Figure 1 The chromosome periphery in human chromosomes.

The spread of metaphase chromosomes was prepared from synchronized HeLa cells with colcemid using Cytospin 4 Cytocentrifuge (Thermo Scientific, Waltham, MA, USA). The chromosome spread was stained with DAPI in blue and immunostained with antibodies against a chromosome periphery protein, nucleolin in green and a centromeric protein, Aurora B, in red, as described previously (49). The immunofluorescent image was acquired using a deconvolution microscopy system (DeltaVision; Applied Precision, Issaquah, WA, USA). The chromosome periphery covers all the surface of mitotic chromosomes including telomeric and centromeric regions.

Depletion of the chromosome periphery also induced aberrations of mitotic spindles. When nucleolin, H1.X, NPM and RRS1 were knocked down, disorganized spindles and multipolar spindles were observed in the depleted cells (28-30, $49,60,82)$. Without centromeres or kinetochores, only DNA-coated beads could assemble the bipolar mitotic spindle in Xenopus egg extracts (83). Taken together, the chromosome periphery might be involved in spindle assembly. Further functional analyses to reveal the interaction and several complexes of CPPs will reveal the structural and functional significance of the CPP network on the chromosome periphery in cell division.

\section{Expert opinion}

Most CPPs are multifunctional proteins. For example, some CPPs are involved in transcription and translation. In functional analyses using RNAi, secondary effects, such as a reduction in RNA metabolism and protein synthesis, were ruled out by confirmation that the expression of proteins other than CPPs was not changed using Western blotting with several antibodies $(49,82)$. However, the side effect of RNAi cannot be excluded completely unless the proteome analysis is performed to confirm all protein expression level. To identify the roles of CPPs in the chromosome periphery, a temporal and spatial-specific knockdown method, for example, chromophore-assisted laser inactivation with a SNAP-tagged protein (84) or Killer-Red protein (85), would be effective.

The chromosome periphery includes some RNAs $(86,87)$. They are not thought to be transcribed during mitosis but to have other functions in the chromosome periphery. Because a part of CPPs including nucleolin and fibrillarin have an RNA recognition motif $(28-30,49)$, they could form a complex with RNA in the chromosome periphery but the CPPRNA network needs to be elucidated by future studies.

\section{Outlook}

The future study of the structure and function of chromosome periphery will provide new insight, which could be applicable to the following processes.

1. Regulation of cell division The chromosome periphery has important roles in cell division events, including chromosome alignment, spindle assembly and chromosome segregation, as mentioned above. Temporal or spatial regulation of CPPs will produce more limited effects in chromosome dynamics rather than directly binding proteins to DNA and microtubules. Furthermore, regulation of the chromosome periphery in the size and localization pattern will contribute to the development of artificial chromosomes or mitotic spindles (88-90).

2. Subcellular transport The chromosome periphery can distribute subcellular components equally to daughter cells. Using the chromosome periphery as a transporter will make it possible to exactly distribute substances, including medicines and chemicals to the next generation through cell division. In particular, nucleolar reassembly is dependent on components in the chromosome periphery. The chromosome periphery consists of only certain nucleolar proteins. Regulation of the amount of specific nucleolar proteins in the chromosome periphery would contribute to nucleolar modification in the component balance, leading to indirect regulation of RNA transcription and protein synthesis $(5,6,91)$.

\section{Highlights}

The chromosome periphery covers the entire surface of chromosomes, including centromeric and telomeric regions. The chromosome periphery has at least three functions, as an insulator or barrier to protect dividing chromosomes from subcellular substances, as a carrier of nuclear and nucleolar 
components for equal distribution to daughter cells and as a regulator of mitotic progression, involving cohesion of sister chromatids, kinetochore-microtubule attachments, spindle assembly and chromosome segregation. The detailed structure and function of the chromosome periphery will be elucidated by analyses of CPPs using temporally and spatially controlled experiments.

\section{References}

1. Zacharias H. Key word: chromosome. Chromosome Res 2001; 9: 345-55.

2. Hernandez-Verdun D, Gautier T. The chromosome periphery during mitosis. BioEssays 1994; 16: 179-85.

3. Zimmerman SB. Shape and compaction of Escherichia coli nucleoids. J Struct Biol 2006; 156: 255-61.

4. McClintock B. The relationship of a particular chromosomal element to the development of the nucleoli in Zea mays. Zeitschr Zellf Mikr Anat 1934; 21: 294-328.

5. Boisvert FM, van Koningsbruggen S, Navascués J, Lamond AI. The multifunctional nucleolus. Nat Rev Mol Cell Biol 2007; 8: 574-85.

6. DiMario PJ. Cell and molecular biology of nucleolar assembly and disassembly. Int Rev Cytol 2004; 239: 99-178.

7. Van Hooser AA, Yuh P, Heald R. The perichromosomal layer. Chromosoma 2005; 114: 377-88.

8. Strasburger, E. Ueber den Theilungsvorgang der Zellkerne und das Verhaltniss der Kerntheilung zur Zelltheilung. Arch Mikroskop Anat 1882; 21: 476-588.

9. Gates RR. Nucleoli and related nuclear structures. Bot Rev 1942; 8: 337-409.

10. Montgomery TH. Comparative cytological studies, with special regard to the morphology of the nucleolus. J Morphol 1898; 15 : 265-582.

11. Sharp LW. Structure of large somatic chromosomes. Bot Gaz 1929; 88: 349.

12. Moyne G, Garrido J. Ultrastructural evidence of mitotic perichromosomal ribonucleoproteins in hamster cells. Exp Cell Res 1976; 98: 237-47.

13. Paweletz N, Risueno MC. Transmission electron microscopic studies on the mitotic cycle of nucleolar proteins impregnated with silver. Chromosoma 1982; 85: 261-73.

14. Ploton D, Thiry M, Menager M, Lepoint A, Adnet JJ, Goessens G. Behaviour of nucleolus during mitosis. Chromosoma 1987; 95: 95-107.

15. Sato S, Sato M. Peculiar behavior of the nucleolus and appearance of cytoplasmic nucleolus-like bodies in the root tip meristems of Brodiaea uniflora Engl. grown at low temperature. Protoplasma 1984; 120: 197-208.

16. Gautier T, Masson C, Quintana C, Arnoult J, Hernandez-Verdun D. The ultrastructure of the chromosome periphery in human cell lines. An in situ study using cryomethods in electron microscopy. Chromosoma 1992; 101: 502-10.

17. Uchiyama S, Kobayashi S, Takata H, Ishihara T, Hori N, Higashi T, Hayashihara K, Sone T, Higo D, Nirasawa T, Takao T, Matsunaga S, Fukui K. Proteome analysis of human metaphase chromosomes. J Biol Chem 2005; 280: 16994-7004.

18. Takata H, Uchiyama S, Nakamura N, Nakashima S, Kobayashi S, Sone T, Kimura S, Lahmers S, Granzier H, Labeit S, Matsunaga S, Fukui K. A comparative proteome analysis of human metaphase chromosomes isolated from two different cell lines reveals a set of conserved chromosome-associated proteins. Genes Cells 2007; 12: 269-84.

19. Haraguchi T, Koujin T, Segura-Totten M, Lee KK, Matsuoka Y, Yoneda Y, Wilson KL, Hiraoka Y. BAF is required for emerin assembly into the reforming nuclear envelope. J Cell Sci 2001; 114: 4575-85.

20. Haraguchi T, Koujin T, Osakada H, Kojidani T, Mori C, Masuda $\mathrm{H}$, Hiraoka Y. Nuclear localization of barrier-to-autointegration factor is correlated with progression of $\mathrm{S}$ phase in human cells. J Cell Sci 2007; 120: 1967-77.

21. Haraguchi T, Kojidani T, Koujin T, Shimi T, Osakada H, Mori C, Yamamoto A, Hiraoka Y. Live cell imaging and electron microscopy reveal dynamic processes of BAF-directed nuclear envelope assembly. J Cell Sci 2008; 121: 2540-54.

22. Barboule N, Truchet I, Valette A. Localization of phosphorylated forms of Bcl-2 in mitosis: co-localization with Ki-67 and nucleolin in nuclear structures and on mitotic chromosomes. Cell Cycle 2005; 4: 590-6.

23. Wetzler M, Talpaz M, Yee G, Stass SA, Van Etten RA, Andreeff M, Goodacre AM, Kleine HD, Mahadevia RK, Kurzrock R. Cell cycle-related shifts in subcellular localization of BCR: association with mitotic chromosomes and with heterochromatin. Proc Natl Acad Sci USA 1995; 92: 3488-92.

24. Angelier N, Tramier M, Louvet E, Coppey-Moisan M, Savino TM, De Mey JR, Hernandez-Verdun D. Tracking the interactions of rRNA processing proteins during nucleolar assembly in living cells. Mol Biol Cell 2005; 16: 2862-71.

25. Pestov DG, Strezoska Z, Lau LF. Evidence of p53-dependent cross-talk between ribosome biogenesis and the cell cycle: effects of nucleolar protein Bop1 on G(1)/S transition. Mol Cell Biol 2001; 21: 4246-55.

26. Morrison C, Henzing AJ, Jensen ON, Osheroff N, Dodson H, Kandels-Lewis SE, Adams RR, Earnshaw WC. Proteomic analysis of human metaphase chromosomes reveals topoisomerase II alpha as an Aurora B substrate. Nucleic Acids Res 2002; 30 : 5318-27.

27. Nayyar VK, Shire K, Frappier L. Mitotic chromosome interactions of Epstein-Barr nuclear antigen 1 (EBNA1) and human EBNA1-binding protein 2 (EBP2). J Cell Sci 2009; 122: 4341-50.

28. Amin MA, Matsunaga S, Ma N, Takata H, Yokoyama M, Uchiyama S, Fukui K. Fibrillarin, a nucleolar protein is required for normal nuclear morphology and cellular growth in HeLa cells. Biochem Biophys Res Commun 2007; 360: 320-6.

29. Amin MA, Matsunaga S, Uchiyama S, Fukui K. Depletion of nucleophosmin leads to distortion of nucleolar and nuclear structures in HeLa cells. Biochem J 2008; 415: 345-51.

30. Amin MA, Matsunaga S, Uchiyama S, Fukui K. Nucleophosmin is required for chromosome congression, proper mitotic spindle formation, and kinetochore-microtubule attachment in HeLa cells. FEBS Lett 2008; 582: 3839-44.

31. Medina FJ, Cerdido A, Fernandez-Gomez ME. Components of the nucleolar processing complex (Pre-rRNA, fibrillarin, and nucleolin) colocalize during mitosis and are incorporated to daughter cell nucleoli. Exp Cell Res 1995; 221: 111-25.

32. Savino TM, Gébrane-Younès J, De Mey J, Sibarita JB, Hernandez-Verdun D. Nucleolar assembly of the rRNA processing machinery in living cells. J Cell Biol 2001; 153: 1097-110.

33. Gassmann R, Henzing AJ, Earnshaw WC. Novel components of human mitotic chromosomes identified by proteomic analysis of the chromosome scaffold fraction. Chromosoma 2005; 113 : 385-97.

34. Moran-Jones K, Wayman L, Kennedy DD, Reddel RR, Sara S, Snee MJ, Smith R. hnRNP A2, a potential ssDNA/RNA molec- 
ular adapter at the telomere. Nucleic Acids Res 2005; 33: 486-96.

35. Takata H, Matsunaga S, Morimoto A, Ono-Maniwa R, Uchiyama S, Fukui K. H1.X with different properties from other linker histones is required for mitotic progression. FEBS Lett 2007; 581: 3783-8.

36. Snee M, Kidd GJ, Munro TP, Smith R. RNA trafficking and stabilization elements associate with multiple brain proteins. J Cell Sci 2002; 115: 4661-9.

37. Kametaka A, Takagi M, Hayakawa T, Haraguchi T, Hiraoka Y, Yoneda Y. Interaction of the chromatin compaction-inducing domain (LR domain) of Ki-67 antigen with HP1 proteins. Genes Cells 2002; 7: 1231-42.

38. Takagi M, Matsuoka Y, Kurihara T, Yoneda Y. Chmadrin: a novel Ki-67 antigen-related perichromosomal protein possibly implicated in higher order chromatin structure. J Cell Sci 1999; 112: 2463-72.

39. Koike M, Awaji T, Kataoka M, Tsujimoto G, Kartasova T, Koike A, Shiomi T. Differential subcellular localization of DNAdependent protein kinase components $\mathrm{Ku}$ and DNA-PKcs during mitosis. J Cell Sci 1999; 112: 4031-9.

40. Dechat T, Gajewski A, Korbei B, Gerlich D, Daigle N, Haraguchi T, Furukawa K, Ellenberg J, Foisner R. LAP2 $\alpha$ and BAF transiently localize to telomeres and specific regions on chromatin during nuclear assembly. J Cell Sci 2004; 117: 6117-28.

41. Westendorf JM, Konstantinov KN, Wormsley S, Shu MD, Matsumoto-Taniura N, Pirollet F, Klier FG, Gerace L, Baserga SJ. $\mathrm{M}$ phase phosphoprotein 10 is a human U3 small nucleolar ribonucleoprotein component. Mol Biol Cell 1998; 9: 437-49.

42. Shen Q, Zheng X, McNutt MA, Guang L, Sun Y, Wang J, Gong Y, Hou L, Zhang B. NAT10, a nucleolar protein, localizes to the midbody and regulates cytokinesis and acetylation of microtubules. Exp Cell Res 2009; 315: 1653-67.

43. Takagi M, Sueishi M, Saiwaki T, Kametaka A, Yoneda Y. A novel nucleolar protein, NIFK, interacts with the forkhead associated domain of Ki-67 antigen in mitosis. J Biol Chem 2001; 276: 25386-91.

44. Fosså A, Siebert R, Aasheim HC, Maelandsmo GM, Berner A, Fosså SD, Paus E, Smeland EB, Gaudernack G. Identification of nucleolar protein No55 as a tumour-associated autoantigen in patients with prostate cancer. Br J Cancer 2000; 83: 743-9.

45. Ochs RL, Stein TW Jr, Chan EK, Ruutu M, Tan EM. cDNA cloning and characterization of a novel nucleolar protein. Mol Biol Cell 1996; 7: 1015-24.

46. Eilbracht J, Reichenzeller M, Hergt M, Schnolzer M, Heid H, Stohr M, Franke WW, Schmidt-Zachmann MS. NO66, a highly conserved dual location protein in the nucleolus and in a special type of synchronously replicating chromatin. Mol Biol Cell 2004; 15: 1816-32.

47. Sinha KM, Yasuda H, Coombes MM, Dent SY, de Crombrugghe B. Regulation of the osteoblast-specific transcription factor Osterix by NO66, a Jumonji family histone demethylase. EMBO J 2010; 29: 68-79.

48. Utama B, Kennedy D, Ru K, Mattick JS. Isolation and characterization of a new nucleolar protein, Nrap, that is conserved from yeast to humans. Genes Cells 2002; 7: 115-32.

49. Ma N, Matsunaga S, Takata H, Ono-Maniwa R, Uchiyama S. Fukui K. Nucleolin functions in nucleolus formation and chromosome congression. J Cell Sci 2007; 120: 2091-105.

50. Ochs R, Lischwe M, O'Leary P, Busch H. Localization of nucleolar phosphoproteins B23 and C23 during mitosis. Exp Cell Res 1983; 146: 139-49.

51. Olson MO, Dundr M, Szebeni A. The nucleolus: an old factory with unexpected capabilities. Trends Cell Biol 2000; 10: 18996.
52. Gao S, Witte MM, Scott RE. P2P-R protein localizes to the nucleolus of interphase cells and the periphery of chromosomes in mitotic cells which show maximum P2P-R immunoreactivity. J Cell Physiol 2002; 191: 145-54.

53. Gao S, Scott RE. Stable overexpression of specific segments of the P2P-R protein in human MCF-7 cells promotes camptothecin-induced apoptosis. J Cell Physiol 2003; 197: 445-52.

54. Lerch-Gaggl A, Haque J, Li J, Ning G, Traktman P, Duncan SA. Pescadillo is essential for nucleolar assembly, ribosome biogenesis and mammalian cell proliferation. J Biol Chem 2002; 277 : 45347-55.

55. Maiorana A, Tu X, Cheng G, Baserga R. Role of pescadillo in the transformation and immortalization of mammalian cells. Oncogene 2004; 23: 7116-24.

56. Li N, Yuan K, Yan F, Huo Y, Zhu T, Liu X, Guo Z, Yao X. PinX1 is recruited to the mitotic chromosome periphery by Nucleolin and facilitates chromosome congression. Biochem Biophys Res Commun 2009; 384: 76-81.

57. Yuan K, Li N, Jiang K, Zhu T, Huo Y, Wang C, Lu J, Shaw A, Thomas K, Zhang J, Mann D, Liao J, Jin C, Yao X. PinX1 is a novel microtubule-binding protein essential for accurate chromosome segregation. J Biol Chem 2009; 284: 23072-82.

58. MacCallum DE, Hall PA. The location of pKi67 in the outer dense fibrillary compartment of the nucleolus points to a role in ribosome biogenesis during the cell division cycle. J Pathol 2000; 190: 537-44.

59. Hugle B, Hazan R, Scheer U, Franke WW. Localization of ribosomal protein $\mathrm{S} 1$ in the granular component of the interphase nucleolus and its distribution during mitosis. J Cell Biol 1985; 100: 873-86.

60. Gambe AE, Matsunaga S, Takata H, Ono-Maniwa R, Baba A, Uchiyama S, Fukui K. A nucleolar protein RRS1 contributes to chromosome congression. FEBS Lett 2009; 583: 1951-6.

61. Magoulas C, Zatsepina OV, Jordan PW, Jordan EG, Fried M. The SURF-6 protein is a component of the nucleolar matrix and has a high binding capacity for nucleic acids in vitro. Eur J Cell Biol 1998; 75: 174-83.

62. Grasberger H, Bell GI. Subcellular recruitment by TSG118 and TSPYL implicates a role for zinc finger protein 106 in a novel developmental pathway. Int J Biochem Cell Biol 2005; 37: 1421-37.

63. Larsson M, Brundell E, Jorgensen PM, Stahl S, Hoog C. Characterization of a novel nucleolar protein that transiently associates with the condensed chromosomes in mitotic cells. Eur J Cell Biol 1999; 78: 382-90.

64. Spector DL, Smith HC. Redistribution of U-snRNPs during mitosis. Exp Cell Res 1986; 163: 87-94.

65. Schandl CA, Li S, Re GG, Fan W, Willingham MC. Mitotic chromosomal bcl-2. I. Stable expression throughout the cell cycle and association with isolated chromosomes. J Histochem Cytochem 1999; 47: 139-49.

66. Willingham MC, Bhalla K. Transient mitotic phase localization of bcl-2 oncoprotein in human carcinoma cells and its possible role in prevention of apoptosis. J Histochem Cytochem 1994; 42: 441-50.

67. Krajewski S, Tanaka S, Takayama S, Schibler MJ, Fenton W, Reed JC. Investigation of the subcellular distribution of the bcl2 oncoprotein: residence in the nuclear envelope, endoplasmic reticulum and outer mitochondrial membranes. Cancer Res 1993; 53: 4701-14.

68. Schandl CA, Li S, Re GG, Fan W, Willingham MC. Mitotic chromosomal bcl-2. II. Localization to interphase nuclei. J Histochem Cytochem 1999; 47: 151-8. 
69. Yasuda Y, Maul GG. A nucleolar auto-antigen is part of a major chromosomal surface component. Chromosoma 1990; 99: 15260.

70. McKeon FD, Tuffanelli DL, Kobayashi S, Kirschner MW. The redistribution of a conserved nuclear envelope protein during the cell cycle suggests a pathway for chromosome condensation. Cell 1984; 36: 83-92.

71. Shi LJ, Ni ZM, Zhao S, Wang G, Yang Y. Involvement of a nucleolar component, perichromonucleolin, in the condensation and decondensation of chromosomes. Proc Natl Acad Sci USA 1987; 84: 7953-6.

72. Hirano T. At the heart of the chromosome: SMC proteins in action. Nat Rev Mol Cell Biol 2006; 7: 311-22.

73. Gautier T, Robert-Nicoud M, Guilly MN, Hernandez-Verdun D. Relocation of nucleolar proteins around chromosomes at mitosis. A study by confocal laser scanning microscopy. J Cell Sci 1992; 102: 729-37.

74. Sato S, Shigematsu T. Light and electron microscopic study on the behavior of the nucleolar material during mitosis in root tip meristems of Vicia faba. Caryologia 1985; 38: 103-20.

75. Wilson EB. The cell in development and heredity, 3rd ed., New York: The Macmillan Company, 1925.

76. Ruchaud S, Carmena M, Earnshaw WC. The chromosomal passenger complex: one for all and all for one. Cell 2007; 131: $230-1$.

77. Sumner AT. Chromosomes: organization and function. Malden, MA: Blackwell Publishers, 2003.

78. Nomura M. Ribosomal RNA genes, RNA polymerases, nucleolar structures, and synthesis of rRNA in the yeast Saccharomyces cerevisiae. Cold Spring Harbor Symp Quant Biol 2001; 66: 555-65.

79. Elbashir SM, Harborth J, Lendeckel W, Yalcin A, Weber K, Tuschl T. Duplexes of 21-nucleotide RNAs mediate RNA interference in cultured mammalian cells. Nature 2001; 411: 494-8.

80. Bridger JM, Kill IR, Lichter P. Association of pKi-67 with satellite DNA of the human genome in early G1 cells. Chromosome Res 1998; 6: 13-24.

81. Ono T, Losada A, Hirano M, Myers MP, Neuwald AF, Hirano
T. Differential contributions of condensin I and condensin II to mitotic chromosome architecture in vertebrate cells. Cell 2003; 115: 109-21.

82. Takata H, Matsunaga S, Morimoto A, Ma N, Kurihara D, OnoManiwa R, Nakagaw M, Azuma T, Uchiyama S, Fukui K. PHB2 protects sister-chromatid cohesion in mitosis. Curr Biol 2007; 17: 1356-61.

83. Heald R, Tournebize R, Blank T, Sandaltzopoulos R, Becker P, Hyman A, Karsenti E. Self-organization of microtubules into bipolar spindles around artificial chromosomes in Xenopus egg extracts. Nature 1996; 382: 420-5.

84. Keppler A, Ellenberg J. Chromophore-assisted laser inactivation of $\alpha$ - and $\gamma$-tubulin SNAP-tag fusion proteins inside living cells. ACS Chem Biol 2009; 4: 127-38.

85. Bulina ME, Lukyanov KA, Britanova OV, Onichtchouk D, Lukyanov S, Chudakov DM. Chromophore-assisted light inactivation (CALI) using the phototoxic fluorescent protein KillerRed. Nat Protoc 2006; 1: 947-53.

86. Beven AF, Lee R, Razaz M, Leader DJ, Brown JW, Shaw PJ. The organization of ribosomal RNA processing correlates with the distribution of nucleolar snRNAs. J Cell Sci 1996; 109: 1241-51.

87. Jiménez-García LF, Segura-Valdez ML, Ochs RL, Rothblum LI, Hannan R, Spector DL. Nucleologenesis: U3 snRNA-containing prenucleolar bodies move to sites of active pre-rRNA transcription after mitosis. Mol Biol Cell 1994; 5: 955-66.

88. Ren X, Tahimic CG, Katoh M, Kurimasa A, Inoue T, Oshimura M. Human artificial chromosome vectors meet stem cells: new prospects for gene delivery. Stem Cell Rev 2006; 2: 43-50.

89. Tsuduki T, Nakano M, Yasuoka N, Yamazaki S, Okada T, Okamoto Y, Masumoto H. An artificially constructed de novo human chromosome behaves almost identically to its natural counterpart during metaphase and anaphase in living cells. Mol Cell Biol 2006; 26: 7682-95.

90. Walczak CE, Heald R. Mechanisms of mitotic spindle assembly and function. Int Rev Cytol 2008; 265: 111-58.

91. Lo SL, Lee C-C, Lai H-J. The nucleolus: reviewing oldies to have new understandings. Cell Res 2006; 16: 530-8. 